\title{
HUBUNGAN PENGETAHUAN IBU HAMIL TENTANG PERTOLONGAN PERSALINAN DENGAN SIKAP IBU DALAM MEMILIH PENOLONG PERSALINAN
}

\section{MATERNAL KNOWLEDGE RELATIONSHIPS ABOUT MATERNITY ATTENDANCE WITH MOTHER'S ATTITUDE IN SELECTING MATERNITY ASSISTANT}

\author{
Nova Winda Setiati ${ }^{1 *}$, Geovani Wati Darwati ${ }^{2}$ \\ ${ }^{1.2}$ Prodi Kebidanan Fakultas IImu Kesehatan Universitas Galuh Ciamis \\ E-mail: novawindasetiati@gmail.com
}

\begin{abstract}
ABSTRAK
Persalinan merupakan peristiwa penting yang senantiasa diingat dalam kehidupan wanita. Pemilihan tempat persalinan akan berdampak terhadap kesehatan ibu bersalin. Meskipun didukung oleh fasilitas dan tenaga kesehatan yang baik masih ditemukan persalinan oleh tenaga kesehatan di rumah, hal ini terjadi di Desa Sukaharja Kabupaten Ciamis. Tujuan penelitian ini adalah menganalisis tingkat pengetahuan ibu hamil dengan sikap yang di ambil dalam pemilihan tempat persalinan di Desa Sukaharja Kecamatan Rajadesa Kabupaten Ciamis. Sampel dalam penelitian ini adalah sebagian dari ibu hamil pada bulan Maret-April 2018. Penelitian ini termasuk jenis kuantitatif dengan metode deskriptif analitik. Penentuan besar sampel pada penelitian ini melalui perhitungan menggunakan rumus sebanyak 30 orang. Teknik pengambilan sampel menggunakan cara total sampling. Faktor-faktor yang mempengaruhi pemilihan tempat dan pertolongan persalinan antara lain tingkat pengetahuan, tingkat pendapatan, sikap, tingkat pendidikan, dukungan keluarga, jarak ke fasilitas kesehatan dan faktor usia. Saran yang dapat peneliti berikan, diharapkan penelitian ini dapat memberikan masukan bagi tenaga kesehatan untuk lebih memperhatikan ibu hamil dan ibu bersalin terutama dalam hal pemilihan tempat persalinan dan pertolongan persalinan yaitu perlunya meningkatkan perhatian program-program pelayanan kesehatan melalui sosialisasi persalinan di fasilitas kesehatan.
\end{abstract}

Kata Kunci : Pengetahuan ibu hamil, Sikap Persalinan

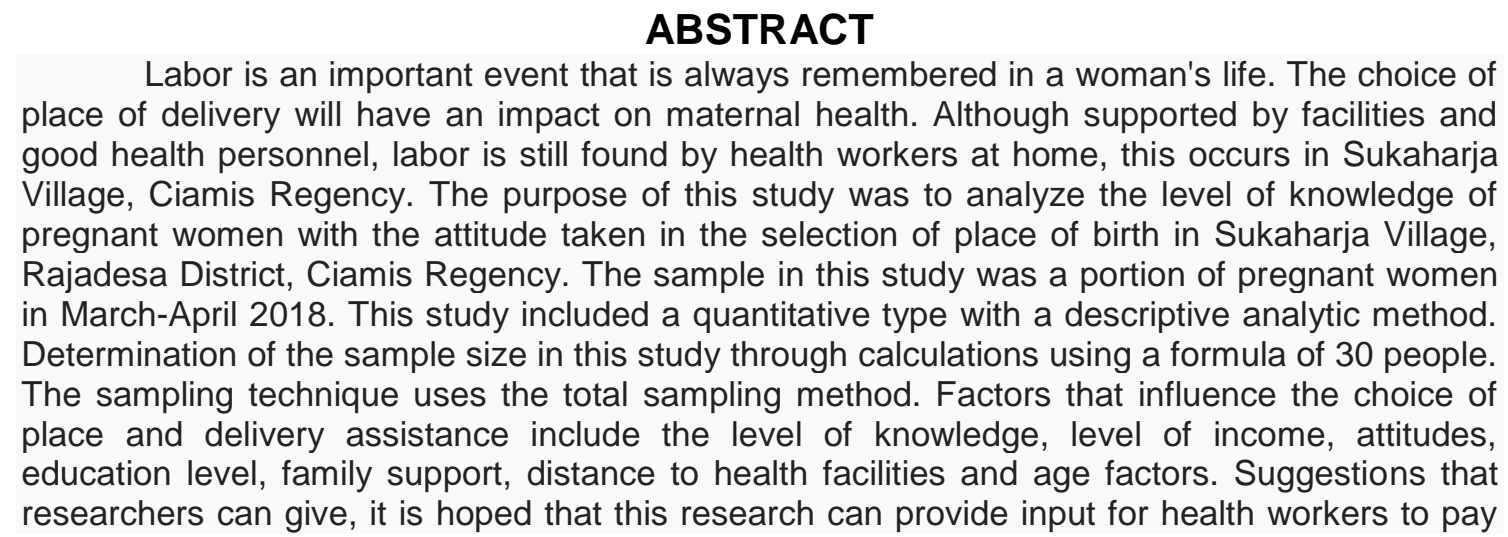


more attention to pregnant women and mothers giving birth, especially in the choice of place of delivery and delivery assistance, namely the need to increase the attention of health care programs through the delivery of information in health facilities.

\section{Keywords : Attitudes of childbirth, Knowledge of pregnant women}

\section{PENDAHULUAN}

Derajat kesehatan suatu negara ditentukan oleh beberapa indikator, salah satu indikator tersebut adalah Angka Kematian Ibu (AKI). Jumlah AKI menurut World Health Organization (WHO) pada tahun 2014 AKI di dunia sebanyak 289.000 jiwa. Berdasarkan Survei Demografi Kesehatan Indonesia (SDKI) tahun 2012, AKI di Indonesia masih tinggi sebesar 359 per 100.000 kelahiran hidup. Target Global Sustainable Development Goals (SDGs) adalah menurunkan AKI menjadi 70 per 100.000 kelahiran hidup. Mengacu dari kondisi saat ini, potensi untuk mencapai target SDGs untuk menurunkan AKI adalah off track, artinya diperlukan kerja keras dan sungguh-sungguh untuk mencapainya. ${ }^{[1]}$

AKI di Provinsi Jawa Barat tahun 2015 yaitu 116,02 per 100.000 kelahiran hidup. ${ }^{[2]}$ Banyak ibu bersalin meninggal dunia karena perdarahan, partus lama, eklampsi, abortus, infeksi, dan lain-lain. Berdasarkan diskusi Gerakan Penyelamatan lbu dan Bayi Baru Lahir di Jawa Barat yang digelar oleh United States Aids for International Development (USAID) bersama Kementrian Kesehatan Jawa Barat ada banyak faktor yang berpengaruh terhadap tingginya AKI yang salah satunya adalah keterlambatan penanganan pasien di fasilitas kesehatan, hal ini yang diakibatkan oleh kurangnya kesadaran ibu hamil tentang pentingnya bersalin di fasilitas kesehatan. ${ }^{[2]}$

Tingginya kasus kematian ibu diidentifikasikan sebagai akibat tidak langsung dari kondisi "tiga terlambat" yaitu: terlambat dalam mengenal tanda bahaya dan mengambil keputusan di tingkat keluarga, terlambat mencapai tempat pelayanan, dan terlambat mendapatkan pertolongan medis yang memadai. ${ }^{[3]}$

Ketidaktahuan ibu hamil tentang pentingnya pertolongan persalinan oleh tenaga kesehatan terampil, persiapan kelahiran, dan kegawatdaruratan merupakan faktor yang mempengaruhi pemanfaatan pelayanan kesehatan ibu dan bayi baru lahir, sehingga ibu cenderung memilih dukun bayi sebagai penolong persalinanny ${ }^{[3]}$ Perilaku pemanfaatan pelayanan kesehatan seseorang selain dipengaruhi oleh sikap dan perilaku petugas serta ketersediaan fasilitas juga dipengaruhi oleh pengetahuan dan sikap masyarakat terhadap kesehatan, tradisi, kepercayaan dan sistem nilai yang lainnya ${ }^{[4]}$ Kehadiran tenaga kesehatan dalam persalinan secara luas dianggap sebagai salah satu strategi intervensi yang paling penting dalam upaya meningkatkan kesehatan ibu di Negara dengan sumber daya rendah.

Pemilihan penolong persalinan terdapat beberapa faktor seperti: pengetahuan. Pengetahuan seseorang mengenai pentingnya melakukan persalinan di fasilitas kesehatan dan kurangnya pengetahuan akan bahaya yang akan terjadi saat ibu hamil melakukan persalinan tanpa di dampingi tenaga kesehatan atau hanya dilakukan oleh tenaga tak terlatih seperti dukun bayi. Bagitu juga faktor pendidikan, semakin tinggi pendidikan seseorang maka akan dapat memilih siapa yang berwenang melakukan pertolongan persalinan. Faktor letak geografis seperti lokasi pemukiman penduduk yang jauh dari lokasi pelayanan kesehatan menjadi alasan untuk memilih malakukan persalinan dengan ditolong oleh non nakes (dukun bayi). Faktor ekonomi menjadi salah satu alasan dimana ibu hamil ingin melakukan persalinan oleh dukun bayi karena tidak terlalu banyak mengeluarkan biaya untuk persalinan, meskipun pemerintah telah mengantisipasi hal tersebut dengan diadakannya kartu kesehatan seperti Badan Penyelenggara Jaminan Sosial (BPJS) dan Kartu Indonesia Sehat (KIS) yang harus dimiliki oleh setiap ibu hamil untuk memperingan biaya yang 
dikeluarkan saat persalinan. Tetapi, akibat kurangnya pengetahuan menjadikan beberapa ibu hamil tidak mengetahui pentingnya dan manfaat dari kartu-kartu kesehatan tersebut. $^{[5]}$

Target cakupan pertolongan persalinan oleh tenaga kesehatan dalam rangka mencapai Indonesia Sehat 2010 adalah sebesar 90\% Namun, data dari Riset Kesehatan Dasar mencatat cakupan persalinan oleh tenaga kesehatan terlatih baru mencapai $82,3 \% .{ }^{[3]}$ Dari data Riskesdas tersebut, sebanyak 43,2\% ibu hamil melahirkan dirumahnya sendiri, dimana hanya $2,1 \%$ yang mendapat pertolongan oleh dokter, bidan 5,9\%, dan tenaga medis lainnya $1,2 \%$, sisanya sebesar $4 \%$ ditolong keluarga dan paling banyak 40,2\% ditolong oleh dukun beranak. $^{[5]}$

Sedangkan, di Jawa Barat tahun 2015 didapatkan bahwa ibu hamil yang bersalin di Non Fasilitas Kesehatan sebanyak 37,7\% dan ibu hamil yang bersalin di fasilitas kesehatan sebanyak 62,3\%. Di Kabupaten Ciamis pada tahun 2017, tingkat kejadian persalinan di non fasilitas kesehatan sebanyak 78 orang. Angka ini sedikit menurun dibandingkan dengan jumlah persalinan di fasilitas kesehatan tahun 2016, yaitu sebanyak 109 orang. ${ }^{[6]}$ Pada tahun 2017 di Desa Sukaharja kejadian persalinan di non fasilitas kesehatan sebanyak 10 orang dan dilihat dari jumlah pada tahun 2016 sebanyak 19 orang angka kejadian persalinan di non fasilitas kesehatan mengalami penurunan, dan pada bulan Januari 2018 terdapat 2 orang yang melakukan persalinan di non fasilitas kesehatan. ${ }^{[13]}$

Berdasarkan hasil studi pendahuluan dengan metode wawancara dengan Bidan Desa Sukaharja, didapatkan bahwa ibu yang tidak melakukan persalinan di fasilitas kesehatan dengan alasan kurangnya pengetahuan mengenai pertolongan persalinan di fasilitas kesehatan, letak geografis warga yang jauh dari tempat pelayanan kesehatan, faktor ekonomi dan ibu mengatakan bahwa merasa tidak nyaman bersalin di fasilitas kesehatan (rumah lebih nyaman dibandingkan di puskesmas atau di Bidan Praktek Mandiri), dan berdasarkan hasil wawancara yang dilakukan pada 10 orang ibu yang bersalin di non fasilitas kesehatan di wilayah Desa Sukaharja Kecamatan Rajadesa Kabupaten Ciamis mengenai persalinan di Non Fasilitas Kesehatan, 8 orang diantaranya menyatakan bahwa alasan tidak bersalin di tenaga kesehatan dengan fasilitas kesehatan yang memadai adalah karena faktor pengetahuan, keterbatasan ekonomi dan jarak ke fasilitas kesehatan yang terlalu jauh, 2 orang diantaranya karena merasa takut bersalin di bidan dan masih mempercayai keyakinan bahwa bersalin di dukun bayi lebih mudah dan nyaman dibandingkan dengan bersalin di tenaga kesehatan dan lebih bersalin dengan ditolong oleh dukun bayi. Dari hasil wawancara diperoleh kesimpulan bahwa beberapa ibu hamil masih kurangnya pengetahuan dan sikap dalam pemilihan penolong persalinan. ${ }^{[14]}$

\section{METODE}

Penelitian ini termasuk jenis penelitian kuantitatif dengan metode deskriptif analitik dengan pendekatan retrospektif melalui observasi atau pengamatan langsung terhadap hubungan pengetahuan dengan sikap ibu hamil dalam pertolongan persalinan.

Populasi dalam penelitian ini adalah ibu hamil di Desa Sukaharja Kecamatan Rajadesa Kabupaten Ciamis periode bulan Maret-April 2018 adalah sebanyak 30 orang yaitu ibu hamil dengan usia kehamilan $4-28$ minggu.

Pengambilan sampel dalam penelitian ini berdasarkan daerah penelitian, dilakukan dengan menggunakan teknik secara total sampling. Total sampling adalah metode pengambilan sampel dimana mengambil seluruh populasi sebagai sampel apabila sampel kurang dari 100, karena jika tidak mengambil semuanya menimbulkan persepsi diskriminasi. $^{[13]}$ Karena sampel di Desa Sukaharja kurang dari 100 maka peneliti menggunakan teknik total sampling.

Variabel sering disebut peubah.

Menurut Setiadi, dalam penelitian terdapat dua variabel, yaitu variabel bebas (independen) dan variabel terikat (dependen). ${ }^{[12]}$

a. Variabel Bebas (variabel independen)

Variabel bebas adalah variabel yang mempengaruhi atau sebab perubahan 
timbulnya variabel terikat (dependen). Variabel independen dalam penelitian ini adalah pengetahuan ibu hamil.

b. Variabel Terikat (variabel dependen)

Variabel dependen adalah variabel yang dipengaruhi, akibat dari adanya variabel bebas (independen). Variabel dependen dalam penelitian ini adalah sikap pertolongan persalinan.

Data yang digunakan dalam penelitian ini adalah data primer dan sekunder.

\section{Uji Validitas}

Validitas merupakan suatu ukuran yang menunjukan tingkatan kevalidan atau kesalahan suatu instrumen. Suatu instrumen dikatakan valid apabila mampu mengukur apa yang diinginkan. Tinggi rendahnya validitas instrumen menunjukan sejauh mana data yang terkumpul tidak menyimpang dari gambaran tentang validitas yang dimaksud ${ }^{[1]}$.

Untuk mengetahui apakah kuesioner yang disusun mampu mengukur apa yang hendak kita ukur, maka perlu diuji dengan uji korelasi skor (nilai) tiap-tiap item (pertanyaan) dengan skor pertanyaan kuesioner tersebut. Teknik korelasi yang diuji dengan uji korelasi yang dipakai adalah teknik korelasi "product moment" karena sample data lebih dari 30 data, dengan rumus sebagai berikut: ${ }^{[13]}$

$$
R=\frac{\mathrm{N}\left(\sum x y\right)-\left(\sum x \sum y\right)}{\sqrt{\left\{N \sum x^{2}-\left(\sum x^{2}\right)\right\}}\left\{N \sum y 2-\left(\sum Y\right)^{2}\right\}}
$$

Keterangan:

$\mathrm{R} \quad$ : Korelasi product moment

$\mathrm{N} \quad$ : Jumlah responden uji coba

$\mathrm{X} \quad$ : Skor pertanyaan

$Y \quad:$ Skor total

XY : Skor pertanyaan dikali skor total.

Dalam melakukan uji validitas jika hasilnya diperoleh $r$ hitung $>r$ tabel, maka pertanyaan-pertanyaan dalam instrumen dapat dikatakan valid.

\section{Uji reliabilitas}

Reliabilitas adalah indeks yang menunjukan sejauh mana suatu alat pengukur dapat dipercaya atau dapat diandalkan. Reliabilitas menunjuk pada tingkat keterandalan, sesuatu yang reliabel artinya dapat dipercaya, jadi instrumen yang digunakan dapat diandalkan ${ }^{[9]}$.
Dan menurut Hidayat (2009), untuk memperoleh indikasi reliabilitas soal dengan menggunakan rumus Spearmen Brown:

$$
r 1=\frac{2 r b}{1+r b}
$$

Keterangan:

r1 : Koefisien reliabilitas internal seluruh item

rb : Koefisien product moment antar belahan

Korelasi antara dua belahan instrumen. Setelah dihitung nilai tersebut kemudian diinterpretasikan berkonsultasi pada harga kritik $r$ product moment, jika $r$ hitung lebih besar dari tabel maka instrumen penelitian tersebut dapat dipercaya sebagai alat pengumpulan data.

Uji validitas dan reliabilitas akan dilakukan pada 10 responden ke desa tetangga yang memiliki ciri dan karakteristik yang sama dengan Desa Sukaharja yaitu Desa Sukajaya Kecamatan Rajadesa Kabupaten Ciamis.

\section{HASIL}

Berikut ini penulis sajikan hasil angket kepada responden dalam hal pengetahuan ibu hamil tentang pertolongan persalinan di Desa Sukaharja Kecamatan Rajadesa Kabupaten Ciamis.

Tabel 1. Distribusi Frekuensi Pengetahuan Ibu Hamil Tentang Pertolongan Persalinan Di Desa Sukaharja Kecamatan Rajadesa.

\begin{tabular}{|c|c|c|c|}
\hline No & Pengetahuan & Frekuensi & $\%$ \\
\hline 1. & Baik & 8 & 26,7 \\
\hline 2. & Cukup & 18 & 60,0 \\
\hline 3. & Kurang & 4 & 13,3 \\
\hline & Jumlah & $\mathbf{3 0}$ & $\mathbf{1 0 0}$ \\
\hline
\end{tabular}

Berdasarkan hasil penelitian yang terlihat pada table 1. pengetahuan ibu hamil tentang pertolongan persalinan di Desa Sukaharja, responden yang pengetahuannya baik sebanyak 8 orang $(26,7 \%)$, dengan pengetahuan cukup sebanyak 18 orang $(60,0 \%)$ dan ibu dengan pengetahuan kurang berjumlah 4 orang (13,3\%). Hal ini 
menunjukkan bahwa sebagian besar ibu hamil di Desa Sukaharja berpengetahuan cukup.

Tabel 2. Distribusi Frekuensi Sikap Ibu Hamil dalam Memilih Penolong Persalinan di Desa Sukaharja Kecamatan Rajadesa

\begin{tabular}{|c|c|c|c|}
\hline No & Sikap & Frekuensi & $\%$ \\
\hline 1. & Mendukung & 11 & 36,7 \\
\hline 2. & $\begin{array}{c}\text { Tidak } \\
\text { Mendukung }\end{array}$ & 19 & 63,3 \\
\hline & Jumlah & $\mathbf{3 0}$ & $\mathbf{1 0 0}$ \\
\hline
\end{tabular}

Berdasarkan hasil penelitian yang terlihat pada tabel 4.2 sikap yang dimiliki ibu hamil dalam memilih penolong persalinan di Desa Sukaharja, ibu hamil dengan sikap mendukung adalah sebanyak 11 orang $(36,7 \%)$ dan ibu hamil dengan sikap tidak mendukung adalah sebanyak 19 orang $(63,3 \%)$. Hal ini menunjukkan bahwa sebagian besar ibu hamil yang berada di Desa Sukaharja Kecamatan Rajadesa adalah memiliki sikap tidak mendukung terhadap pemilihan penolong persalinan.

Adapun hubungan antara pengetahuan ibu hamil dengan sikap ibu dalam memilih penolong persalinan di Desa Sukaharja Kecamatan menunjukkan bahwa proporsi tingkat pengetahuan pada ibu hamil berdasarkan sikap ibu hamil yang mendukung dalam memilih penolong persalinan dari ibu yang berpengetahuan baik dihasilkan sebanyak 8 orang (100\%), dari ibu yang pengetahuannya cukup 2 orang $(11,1 \%)$, dan dari ibu yang pengetahuannya kurang 1 orang $(25,0 \%)$. Sedangkan sikap ibu yang tidak mendukung dalam memilih penolong persalinan dari ibu yang pengetahuannya cukup sebanyak 16 orang $(88,9 \%)$ dan dari ibu yang pengetahuannya kurang berjumlah 3 orang $(75,0 \%)$.

Berdasarkan hasil uji statistik Chi Square dihasilkan $x^{2}=19,115$ dengan p.Value 0,000 . Kemudian nilai tersebut diinterpretasikan dengan membandingkan kepada harga kritik Chi Square didapatkan $x^{2}$ tabel dengan df $=2$ pada interval kepercayaan 95\% (taraf signifikan 5\% adalah 5,991 atau p.Value 0,05). Hal ini berarti responden dengan pengetahuan cukup memiliki peluang sikap tidak mendukung dalam memilih penolong persalinan sebesar 19,115 kali dibandingkan dengan responden dengan tingkat pengetahuan baik. Jadi terdapat hubungan yang bermakna antara pengetahuan ibu hamil dengan sikap ibu hamil dalam memilih penolong persalinan di Desa Sukaharja Kecamatan Rajadesa Kabupaten Ciamis.

\section{PEMBAHASAN}

Hasil penelitian yang telah disajikan dalam bentuk tabel dengan jumlah responden 30 ibu hamil menunjukan bahwa sebagian besar responden (88,9\%) memiliki pengetahuan yang cukup dan sikap tidak mendukung terhadap pemilihan penolong persalinan di fasilitas kesehatan dan hal ini menunjukan bahwa terdapat hubungan antara pengetahuan ibu hamil tentang pertolongan persalinan dengan sikap ibu dalam memilih penolong persalinan.

Faktor pengetahuan ibu hamil yang kurang baik dan menyebabkan ibu tidak mendukung untuk memilih bersalin oleh tenaga kesehatan. Pengetahuan seseorang mengenai pentingnya melakukan persalinan di fasilitas kesehatan dan kurangnya pengetahuan akan bahaya yang akan terjadi saat ibu hamil melakukan persalinan tanpa di dampingi tenaga kesehatan atau hanya dilakukan oleh tenaga kesehatan tak terlatih seperti dukun bayi. Hal ini sesuai dengan pendapat yang dikemukakan yaitu Pengetahuan atau kognitif merupakan domain yang sangat penting untuk terbentuknya tindakan seseorang (overt behavior). ${ }^{[4]}$ Tanpa pengetahuan seseorang tidak mempunyai dasar untuk mengambil keputusan dan menentukan sikap terhadap masalah yang dihadapi.

Pengetahuan adalah salah satu faktor yang mempengaruhi seseorang dalam bersikap termasuk sikap ibu hamil dalam memilih penolong persalinan. Faktor-faktor yang mempengaruhi pengetahuan yaitu sosial ekonomi, budaya, pendidikan, dan pengalaman. Apabila status ekonomi baik tingkat pendidikan akan tinggi, diiringi oleh peningkatan pengetahuan. Budaya berpengaruh terhadap tingkat pengetahuan karena informasi yang baru akan disaring dan 
disesuaikan dengan budaya yang ada serta agama yang dianut, pendidikan yang tinggi akan berpengaruh pada penerimaan hal-hal baru dan dapat menyesuaikan diri. Pengetahuan akan membentuk sikap untuk pengambilan keputusan terhadap pemilihan penolong persalinan di fasilitas kesehatan yang memadai.

\section{SIMPULAN DAN SARAN}

Berdasarkan hasil penelitian dan pembahasan dapat diperoleh kesimpulan bahwa:

1. Tingkat pengetahuan ibu hamil di Desa Sukaharja Kecamatan Rajadesa diketahui bahwa hampir sebagian besar adalah berpengetahuan cukup tentang pertolongan persalinan sebanyak 18 orang $(60,0 \%)$.

2. Sikap ibu hamil dalam memilih penolong persalinan di Desa Sukaharja Kecamatan Rajadesa dihasilkan lebih banyak ibu hamil yang tidak mendukung terhadap pemilihan penolong persalinan seperti halnya oleh tenaga kesehatan terlatih serta di fasilitas kesehatan adalah sebanyak 19 orang $(63,3 \%)$.

3. Setelah dilakukan uji statistik dengan menggunakan Chi Square diperoleh bahwa Ada hubungan antara pengetahuan ibu hamil tentang pertolongan persalinan dengan sikap ibu dalam memilih penolong persalinan.

Sebagai bahan masukan dalam asuhan kebidanan mengenai hubungan tingkat pengetahuan ibu hamil tentang pertolongan persalinan dengan sikap ibu hamil dalam memilih penolong persalinan, menambah wawasan dan informasi tentang pertolongan proses persalinan, sehingga dapat memberikan pemahaman ketika akan memilih penolong persalinan, diharapkan dapat memberikan konseling pada ibu hamil sehingga lebih siap menjalani proses persalinan dan konsisten dalam memilih penolong persalinan dengan cara pemberian penyuluhan mengenai persalinan yang aman.
1. Pusat Data dan Informasi Kementrian Kesehatan RI, 2014

2. Dinkes Jawa Barat. Profil Dinas Kesehatan Jawa Barat Tahun 2015.

3. Depkes RI, Faktor-faktor penyebab kematian ibu di Indonesia. Jakarta, 2010.

4. Notoatmodjo. Metodologi Penelitian Kesehatan., Jakarta : Rineka, 2010.

5. Pramudiarja. Buku Saku Kebidanan. Edisi II. Jakarta: Salemba Medika, 2011.

6. Dinkes Kab. Ciamis. Angka Kejadian Persalinan di Non Fasilitas Kesehatan di Kabupaten Ciamis tahun 2017.

7. Notoatmodjo. Konsep Dasar Kebidanan dan Keperawatan, Teori dan Aplikasinya. Jakarta: Rineka Cipta, 2012.

8. Health. Managemen dan konsep pengetahuan dan aplikasi konsep dasar kepustakaan, 2009.

9. Arikunto, S. Prosedur Penelitian Suatu Pendekatan Praktek. Edisi II. Jakarta: Rieneka Cipta, 2010.

10. Nugroho, Metodologi Penelitian Kesehatan. Jakarta: PT Rineka Cipta, 2014.

11. Sulistiyawati. Buku panduan ibu hamil. Yogyakarta. Graha llmu, 2009.

12. Setiadi. Konsep Penulisan Riset Keperawatan. Yogyakarta: Graha IImu, 2008.

\section{DAFTAR PUSTAKA}

